\title{
THE EFFECT OF DIFFERENT HAEMOGLOBINS ON THE GLUCOSE-6-PHOSPHATE DEHYDROGENASE DEFICIENCY SCREENING TEST (BREWER'S TEST)
}

\author{
R Sugathadasa, D M Dissanayake \\ Department of Pathology, Faculty of Medicine, University of Peradeniya
}

\begin{abstract}
Glucose-6-phosphate dehydrogenase (G6PD) deficiency and haemoglobinopathies are common causes of haemolytic anaemia in Sri Lanka. Even though G6PD enzyme assay is indicated for diagnosis of G6PD deficiency, due to lack of reagents many of the government hospitals in Sri Lanka make the diagnosis only on the basis of a screening test (Brewer's test) for this deficiency. Both these tests are indicated in patients with chronic haemolytic anaemia. The aim of the study was to observe the effect of different haemoglobins on screening test for G6PD deficiency. We investigated the patients and carriers for commoner haemoglobinopathies ( $\mathrm{Hb}$ $\mathrm{E}, \mathrm{Hb} \mathrm{S}$, and $\mathrm{Hb} \mathrm{D}$ ) and thalassaemias using G6PD deficiency screening test as well as G6PD enzyme assay. The results show that patients with $\mathrm{Hb} E / \beta$ thalassaemia, $\mathrm{Hb} \mathrm{E}$ trait and $\mathrm{Hb} \mathrm{E}$ disease gave a false positive reaction with G6PD screening test $(n=47)$, even though their G6PD enzyme levels were normal. Two subjects with $\mathrm{Hb} \mathrm{E}$ showed low enzyme levels with positive screening test. $\mathrm{Hb} \mathrm{S}(\mathrm{n}=5)$ and $\mathrm{Hb} \mathrm{D}(\mathrm{n}=2)$ did not have any effect on the screening test for G6PD deficiency. The patients with $\mathrm{Hb} \mathrm{E}$ and normal enzyme levels are likely to be misdiagnosed as having G6PD deficiency, if only the screening test is utilized. This study emphasizes the necessity for employing an enzyme assay method for the diagnosis of G6PD deficiency, at least in districts with high $\mathrm{Hb}$ E prevalence.
\end{abstract}

Keywords: G6PD, Brewer's test, thalassaemia, haemoglobinopathy.

\section{Introduction}

Glucose 6 phosphate dehydrogenase (G6PD) deficiency is the commonest enzymopathy causing haemolytic anaemia in human beings. It is the most common cause of jaundice and acute haemolytic anaemia in South East Asia. Other causes of haemolytic anaemias in Sri Lanka are Haemoglobinopathies, and less commonly hereditary spherocytosis.

Address for correspondence: D M Dissanayake, Department of Pathology, Faculty of Medicine, University of Peradeniya, Sri Lanka.

e-mail: dhammikamdisa@yahoo.co.uk 
Some haemoglobinopathies and thalassaemias show a particular geographical distribution globally as well as in Sri Lanka. Haemoglobin E which is the commonest haemoglobinopathy in Sri Lanka is more prevalent in Kurunegala, Kandy, and Badulla and in Anuradhapura districts. Beta thalassaemia major also is more prevalent in Kurunegala Kandy, Badulla and Anuradhapura districts. ${ }^{1}$

The haemoglobinopathies and thalassaemic syndromes causing chronic haemolytic anaemia in Sri Lanka include $\beta$ thalassaemia major, $\beta$ thlassaemia intermedia, $\mathrm{Hb} E / \beta$ thalassaemia, Sickle cell anaemia, $\mathrm{Hb} \mathrm{S} / \beta$ thalassaemia and $\mathrm{Hb} \mathrm{D} / \beta$ thalassaemia.

It is believed that there is a protective effect against malaria in patients heterozygous for $\mathrm{Hb} S$ and thalassaemias. ${ }^{2}$ There is a similar selective advantage of carrier states for G6PD deficiency. ${ }^{3}$ In Sri Lanka the incidence of thalassaemia, $\mathrm{Hb}$ E, and G6PD deficiency corresponds to areas where malaria had been at one time endemic or hyper endemic for more than 700 years, i.e. the North Central province, North Western Province and Northern and Eastern divisions of Matale District. ${ }^{4}$

The laboratory investigation of chronic haemolytic anaemia include blood picture, screening test and enzyme assay to exclude G6PD deficiency. Haemoglobinopathies and thalassaemic syndromes are excluded by haemoglobin electrophoresis. Even though G6PD enzyme assay is indicated for diagnosis of G6PD deficiency, due to lack of reagents most government hospitals in Sri Lanka employ only a screening test (Brewer's test) for diagnosis. ${ }^{5}$ The Screening test is performed on fresh blood and the haemoglobin electrophoresis is performed few weeks later only when the laboratory receives an adequate number of samples for the test. Hence the report is delayed for a few weeks. Correct diagnosis of G6PD deficiency is important as patients should avoid exposure to certain drugs and precipitating factors. Correct diagnosis of haemoglobinopathies and thalassaemias are important as parents of patients need genetic counseling to prevent having more children with similar disorders. In some Thalassaemic syndromes the patients may need special treatment to prevent iron overload while this is not indicated in G-6-PD deficiency.

The aim of this study was to observe the effect of the different haemoglobins on the screening test for G6PD deficiency (Brewer's test).

\section{Material and method}

We investigated the patients and carriers for common haemoglobinopathies ( $\mathrm{Hb} \mathrm{E}, \mathrm{Hb} \mathrm{S}, \mathrm{Hb} \mathrm{D})$ and thalassaemias using a G6PD deficiency screening test as well as G6PD enzyme assay. The screening test used was the methhaemoglobin $(\mathrm{Hi})$ reduction test developed by Brewer et al. ${ }^{5}$ In this test sodium nitrite converts haemoglobin $(\mathrm{Hb})$ to $\mathrm{Hi}$. When no methylene blue is added, 
methhaemoglobin persists, but the incubation of the sample with methylene blue allows stimulation of the pentose phosphate pathway in subjects with normal G6PD levels. The Hi is reduced during the incubation period. In G6PD deficient subjects, the block in the pentose phosphate pathway prevents this reduction. The presence of $\mathrm{Hi}$ or $\mathrm{Hb}$ is detected by assessing the colour of the reagent mixture. Normal blood yields a clear red colour and the blood from deficient subjects give a brown colour. Heterozygotes give intermediate reactions. In every test the colour is assessed in comparison to the positive and negative controls prepared in the laboratory. The haemoglobinopathies and thalassaemic syndromes were confirmed by electrophoresis at alkaline and acidic $\mathrm{pH}$ values. The number of patients belonging to each category of haemoglobinopathy included in the study is indicated in table 1.

\section{Results}

The results of the G6PD screening test and G6PD assay are shown in table 1.

Table 1. Results of G6PD Screening test and G6PD assay in each group of patients with different haemoglobin disorders

\begin{tabular}{|llllll|}
\hline Diagnosis & Total no. & Screening test & \multicolumn{2}{l|}{ G6PD assay } \\
& of cases & Negative & Positive & Negative & Positive \\
\hline$\beta$ Thalasaemia major & 11 & 11 & 0 & 11 & 0 \\
\hline$\beta$ thalassaemia trait & 09 & 09 & 0 & 09 & 0 \\
\hline Hb E/ $\beta$ thlassaemia & 26 & 0 & 26 & 26 & 0 \\
\hline Hb E disease & 10 & 0 & 10 & 10 & 0 \\
\hline Hb E trait & 13 & 0 & 13 & 11 & 2 \\
\hline Sickel cell anaemia & 03 & 03 & 0 & 03 & 0 \\
\hline Hb S trait & 01 & 01 & 0 & 01 & 0 \\
\hline Hb S/ $\beta$ thalassaemia & 02 & 02 & 0 & 02 & 0 \\
\hline Hb S/D & 01 & 01 & 0 & 01 & 0 \\
\hline Total & 76 & 27 & 49 & 74 & 02 \\
\hline
\end{tabular}

The results show that $\mathrm{Hb} \mathrm{E}$ present in $\mathrm{Hb} \mathrm{E} / \beta$ thalassaemia, $\mathrm{Hb}$ E trait and $\mathrm{Hb} \mathrm{E}$ disease, gives a false positive reaction with G6PD screening test, even though their G6PD enzyme levels were normal. Two subjects with $\mathrm{Hb} \mathrm{E}$ trait showed low enzyme levels with positive screening test. All the patients with $\mathrm{Hb}$ E showed positive results with G6PD screening test, irrespective of the G6PD enzyme levels. $\mathrm{Hb} \mathrm{S}(n=5)$ and $\mathrm{Hb} \mathrm{D}(n=2)$ did not show any effect on the screening test for G6PD deficiency. 


\section{Discussion}

The present study demonstrates that the patients with $\mathrm{Hb}$ E give false positive results with a screening test for G6PD. Consequently reliance on screening test alone may lead to a misdiagnosis of G6PD deficiency in patients with $\mathrm{Hb} \mathrm{E}$. The fact that presence of $\mathrm{Hb} \mathrm{E}$ leads to false positive results in the screening test has not been reported previously.

The Brewer's test is based on the ability of sodium nitrite to convert $\mathrm{Hb}$ to $\mathrm{Hi}$. When no methylene blue is added, methhaemoglobin persists, but incubation of the samples with methylene blue allows stimulation of the pentose phosphate pathway in subjects, with normal G6PD levels. In G6PD deficient subjects, the block in the pentose phosphate pathway prevents this reduction. The reason for false positive Brewer's test in patients with $\mathrm{Hb} \mathrm{E}$ is not known. It could be due to the unstable nature of $\mathrm{Hb}$ E leading to the requirement of more NADPH to maintain the normal red cell membrane.

Hemoglobin $E(\beta 26$, GAG-AAG, Glu-Lys), has been shown to be unstable at high temperatures. Time-course globin chain synthesis experiments have revealed that instability is not an important factor in the steady state, but that at 41 degrees Celsius newly synthesized $\mathrm{Hb}$ molecules are unstable. ${ }^{6}$ Haemoglobin $E$ is oxidatively unstable possibly because a weakened alpha beta globin chain contact results in increased susceptibility to oxidative damage. ${ }^{7}$ Hemoglobin instability may be important during febrile episodes, contributing to worsening anemia. It is also observed that the patients with $\mathrm{Hb} \mathrm{E}$ and $\mathrm{Hb} \mathrm{H}$ develop severe anaemia during fever episodes probably due to increased susceptibility to oxidative haemolysis. ${ }^{8}$

$\mathrm{Hb} \mathrm{E}$ is the commonest haemoglobinopathy in Sri Lanka, with high prevalence in Kurunegala, Kandy, Anuradhapura and Badulla districts. The patients with $\mathrm{Hb} \mathrm{E}$ are likely to be labeled with G6PD deficiency, while having normal enzyme levels, if only the screening test is utilized in the diagnosis. This implies the necessity for employing an enzyme assay method for the diagnosis of G6PD deficiency, at least in districts with high $\mathrm{Hb}$ E prevalence.

\section{References}

1. de Silva S, Fisher CA, Premawardhena A et al. Thalassaemia in Sri Lanka: implications for the future health burden of Asian populations. Sri Lanka Thalassaemia Study Group 2000. Lancet. Mar 4; 355(9206): 786-91.

2. Allison AC. The distribution of the sickle-cell trait in East Africa and elsewhere, and its apparent relationship to the incidence of subtertian malaria. Trans $R$ Soc Trop Med Hyg. 1954 Jul; 48(4): 312-8. 
3. Than AM, Harano $\mathrm{T}$, Harano $\mathrm{K}$ et al. High incidence of 3-thalassemia, hemoglobin $\mathrm{E}$ and glucose-6-phosphate dehydrogenase deficiency in populations of malaria-endemic southern Shan State. Myanmar Int J Hematol. 2005 Aug; 82(2): 119-23.

4. Nagaratnam N, Leelawathie PK, Weerasinghe WM. Enzyme glucose-6-phosphate dehydrogenase (G6PD) deficiency among Sinhalese in Ceylon as revealed by the methaemoglobin reduction test. Ind J Med Res. 1969 Mar; 57(3): 569-72.

5. Brewer GJ, Tarlov AR, Alving AS. The methhaemoglobin reduction test for primaquine-type sensitivity of erythrocytes. A simplified procedure for detecting a specific hypersusceptibility to drug haemolysis. Journal of the American Medical Association. 1962; 180: 386.

6. Rees DC, Clegg JB, Weatherall DJ. Is hemoglobin instability important in the interaction between hemoglobin E and beta thalassemia? Blood. 1998 Sep 15; 92(6): 2141-6.

7. Frischer $\mathrm{H}$, Bowman J. Haemoglobin $\mathrm{E}$, an oxidatively unstable mutation. J Lab Clin Med. 1975 Apr; 85 (4): 531-9.

8. Jetsrisuparb A, Sanchaisuriya K, Fucharoen G, Fucharoen S, Wiangnon S, Jetsrisuparb C et al. Development of severe anemia during fever episodes in patients with hemoglobin $E$ trait and hemoglobin H disease combinations. J Pediatr Hematol Oncol. 2006 Apr; 28(4): 249-53. 